\title{
AZEREDO COUTINHO, VISCONDE DE ARARUAMA E A MEMÓRIA SOBRE O COMÉRCIO DOS ESCRAVOS DE $1838^{*}$
}

\author{
Rafael de Bivar Marquese \\ Departamento de História - FFLCH/USP \\ Tâmis Peixoto Parron \\ Bolsista de Iniciação Científica - DH - FFLCH/USP
}

\begin{abstract}
Resumo
Em 1838, foi publicada anonimanente no Rio de Janeiro uma Memória sobre o comércio dos escravos. A historiografia considera o bispo José Joaquim da Cunha de Azeredo Coutinho como o autor do documento. O artigo critica essa atribuição, creditando a Memória a José Carneiro da Silva, $1^{\circ}$ Visconde de Araruama. Por fim, contextualiza sua defesa do tráfico negreiro no quadro dos debates políticos da década de 1830 .
\end{abstract}

\section{Pallavras-Chave}

Tráfico negreiro • Ideologia da escravidão • Império do Brasil

\section{Abstract}

In 1838 , a paper on the slave trade was published anonymously in Rio de Janeiro. Historians have considered bishop José Joaquim da Cunha de Azeredo Coutinho to be the author of the document. This article criticizes such attribution and ascribes it to José Carneiro da Silva, $1^{\text {st }}$ Viscount of Araruama. Finally, the authors place Silva's defense of the slave trade within the context of the political debates of the 1830s.

\section{Keywords}

Slave trade • Ideology of slavery $\bullet$ Brazilian Empire

\footnotetext{
* Este artigo foi escrito no âmbito do Projeto Temático "A fundação do Estado e da Nação: Brasil c.1780-c.1850". Tâmis Peixoto Parron agradece o financiamento da FAPESP à sua pesquisa.
} 


\section{0 problema da atribuição}

Em 1838, foi publicado anonimamente no Rio de Janeiro, pela Tipografia Imperial e Constitucional de Júlio Villeneuve, um opúsculo intitulado Memória sobre comércio dos escravos, em que se pretende mostrar que este tráfico $e ́$, para eles, antes um bem do que um mal. A folha de rosto indicava unicamente que a memória havia sido escrita por um "natural de Campos dos Goitacases". Talvez associando de forma imediata a existência de poucas defesas abertas da escravidão na história do Brasil ao fato de o bispo José Joaquim da Cunha de Azeredo Coutinho (1742-1821) ter sido um de seus maiores expoentes, a crítica histórica do século XX creditou a autoria da memória a esse ilustre prelado, também filho dos Campos dos Goitacases.

Ao que tudo indica, o primeiro a fazê-lo foi o bibliógrafo Rubens Borba de Moraes, seguindo uma sugestão de Sacramento Blake. Na bibliografia que elaborou para a edição dos escritos econômicos de Azeredo Coutinho, cuja apresentação ficou a cargo de Sérgio Buarque de Holanda, Moraes não teve dúvidas em inscrever a memória no corpus do bispo ${ }^{1}$.

A atribuição feita pelo grande bibliógrafo, inserida em um volume preparado pelo grande historiador, levou alguns especialistas a aceitarem a autoria da memória como sendo de Azeredo Coutinho. Isso pode ser verificado em dois trabalhos significativos escritos nos últimos vinte anos sobre o problema da escravidão no Império do Brasil. Assim, Luiz Felipe de Alencastro, ao comentar em sua tese de doutorado a célebre defesa do tráfico negreiro apresentada por Bernardo Pereira de Vasconcelos na década de 1840, que professava os efeitos benéficos da escravidão para a construção da ordem nacional ("nossa civilização provém da costa da África (...), porque daquele continen-

\footnotetext{
${ }^{1}$ Cf. COUTINHO, J.J.da Cunha de Azeredo. Obras econômicas. Apresentação de Sérgio B. de Holanda. São Paulo: Companhia Editora Nacional, 1966, "Bibliografia de Azeredo Coutinho", p.315. Blake, entretanto, não foi conclusivo em sua atribuição; após sumariar o conteúdo da Análise sobre a justiça do comércio do resgate dos escravos da costa da África, escreveu a seguinte frase: "Penso que é a mesma obra publicada mais tarde com o título Memória sobre o comércio dos escravos (...)." BLAKE, A.V.A. S. Diccionario Bibliographico Brazileiro. Rio de Janeiro: Imprensa Nacional, 1898, 7v, v.4, p.477. Tancredo de Barros Paiva, em suas Achêgas a um diccionario de pseudonymos... (Rio de Janeiro: J.Leite e Cia, 1929, item 826), também atribuiu a Memória a Azeredo Coutinho. Agradecemos essa referência a Cristina Antunes, da Biblioteca José Mindlin.
} 
te veio o trabalhador robusto, o único que sob este céu africano e num clima mais inclemente então que hoje, poderia ter produzido, como produziu, as riquezas que proporcionaram a nossos pais recursos para mandar seus filhos estudar nas academias e universidades da Europa, ali adquirirem os conhecimentos de todos os ramos do saber, os princípios da Filosofia do Direito, em geral, e do Direito Público Constitucional que impulsionaram e apressaram a Independência e presidiram à organização consagrada na Constituição e noutras leis orgânicas, ao mesmo tempo fortalecendo a liberdade"), a contrapôs à linha de argumentação de Azeredo Coutinho em sua Análise sobre a Justiça do Comércio do Resgate dos Escravos da Costa da África (1ª ed: 1798), atrelada a uma compreensão global do sistema colonial português. Nas palavras de Alencastro, "na medida em que apresenta o tráfico como necessário à manutenção de Portugal, Azeredo Coutinho não pode mais legitimar o tráfico ilegal brasileiro no século XIX. Daí a razão de seu ensaio ser editado anonimamente no Rio em 1838."

Por sua vez, Jaime Rodrigues, em ótima monografia a respeito das propostas e experiências em torno do final do tráfico transatlântico para o Brasil, classificou Azeredo Coutinho entre os poucos homens de letras e políticos que, no contex to dos debates da primeira metade do século XIX, defenderam simultaneamente a manutenção do tráfico e da escravidão. Para tanto, Rodrigues se valeu da Análise de 1798, das Concordâncias das leis de Portugal, e das bulas pontifícias, das quais umas permitem a escravidão dos pretos d'África, e outras proíbem a escravidão dos índios do Brasil ( $1^{a}$ ed: 1808), e da Memória sobre o comércio dos escravos de 1838 , tomando esses documentos como expressão do pensamento de Azeredo Coutinho sobre o assunto ${ }^{3}$.

\footnotetext{
${ }^{2}$ ALENCASTRO, Luiz Felipe de. Le Commerce des Vivants: Traite d'Esclaves et "Pax Lusitana" dans l'Atlantique Sud. Tese de Doutorado. Paris: Université de Paris X, 19851986, 3v, v.3, p.553, n.142. A respeito do discurso de Vasconcelos, Alencastro (v.3, p.516) afirma que foi pronunciado em sessão de 1840 no Senado, e, em rodapé, indica que retirou a citação de Oliveira Lima. Na passagem em questão, no entanto, esse autor não precisa a data do discurso de Vasconcelos. Ver LIMA, O. O império brasileiro (18211889). $2^{a}$ ed. Belo Horizonte/São Paulo: Itatiaia/Edusp, 1989, p.106. Em pesquisa sobre a ideologia da escravidão no Parlamento Brasileiro, Tâmis Peixoto Parron não localizou a fala de Vasconcelos nos Anais do Senado de 1840.

${ }^{3}$ Cf. RODRIGUES, Jaime. O infame comércio. Propostas e experiências no final do tráfico de africanos para o Brasil (1800-1850).Campinas: Ed.Unicamp/Cecult/FAPESP, 2000, pp.71-2.
} 
Contudo, salvo esses dois exemplos, a memória publicada em 1838 recebeu pouca atenção da historiografia. Ela sequer foi citada nos trabalhos mais relevantes que trataram da discussão ideológica sobre a escravidão negra no Segundo Império ${ }^{4}$. Os demais textos escravistas de Azeredo Coutinho, pelo contrário, foram analisados em profundidade por diferentes historiadores ${ }^{5}$. Essa atitude derivou, muito provavelmente, da atribuição de Rubens Borba de Moraes. Afinal, por que analisar um texto impresso quase vinte anos após a morte de seu autor, se o mesmo não passava de uma reimpressão de escritos publicados anteriormente?

\footnotetext{
${ }^{4}$ Ver, a respeito, as seguintes publicações: COSTA, Emília Viotti da. Da Senzala à Colônia. (1ª.ed: 1966). São Paulo: Brasiliense, 1989; BETHELL, Leslie. A abolição do tráfico de escravos no Brasil: A Grã-Bretanha, o Brasil e a questão do tráfico de escravos, 1807-1869. (Trad.port.) São Paulo: Edusp - Expressão e Cultura, 1976; CONRAD, Robert. Os últimos anos da escravatura no Brasil, 1850-1888. (1ª .ed: 1972; trad.port.). Rio de Janeiro: Civilização Brasileira, 1978; QUEIRÓZ, Suely Robles Reis de. "Aspectos ideológicos da escravidão”. In: Estudos Econômicos. 13 (1): 85-101, jan./abr.1983; CONRAD, Robert. Tumbeiros. O tráfico de escravos para o Brasil. (trad.port.) São Paulo: Brasiliense, 1985; MATTOS, Ilmar Rohloff de. O Tempo Saquarema. A Formação do Estado Imperial. São Paulo: Hucitec, 1987; CARVALHO, José Murilo de. "Escravidão e razão nacional”. In: Dados - Revista de Ciências Sociais. 31 (3): 287-308, 1988; GRADEN, Dale T. "An Act 'Even of Public Security': Slave Resistance, Social Tensions, and the End of the International Slave Trade to Brazil, 1835-1856". In: Hispanic American Historical Review. 76 (2): 248-282, may 1996; MATTOS, Hebe Maria. Escravidão e cidadania no Brasil monárquico. Rio de Janeiro: Jorge Zahar Editor, 2000; NEEDELL, Jeffrey. "The Abolition of the Brazilian Slave Trade in 1850: Historiography, Slave Agency and Statesmanship". In: Journal of Latin American Studies. 33 (4): 681-711, november 2001; GRINBERG, Keila. O fiador dos brasileiros. Cidadania, escravidão e direito civil no tempo de Antonio Pereira Rebouças. Rio de Janeiro: Civilização Brasileira, 2002; REIS, João José. Rebelião escrava no Brasil. A história do levante dos Malês em 1835. Ed.revista e ampliada. São Paulo: Companhia das Letras, 2003.

${ }^{5}$ Cf. SIQUEIRA, Sônia Aparecida. "A escravidão negra no pensamento do bispo Azeredo Coutinho." (1 ${ }^{\mathrm{a}}$ ed: 1964). In: SILVA, Leonardo Dantas (org.) Estudos sobre a escravidão negra 1. Recife: Fundação Joaquim Nabuco - Editora Massangana, 1988; VAINFAS, Ronaldo. "Idéias reacionárias no Brasil no final do século XVIII: a defesa do colonialismo e da escravidão na obra de Azeredo Coutinho (1724-1821)." In: L'Amérique Latine face à la Revolution Française. Paris : Association Française des Sciences Sociales sur l'Amérique Latine, 1989; NEVES, Guilherme Pereira das. "Pálidas e oblíquas luzes: J.J.da C. Azeredo Coutinho e a Análise sobre a justiça do comércio do resgate dos escravos." In: SILVA, Maria Beatriz Nizza da (org.). Brasil: Colonização e Escravidão. Rio de Janeiro: Nova Fronteira, 1996; NEVES, Guilherme Pereira das. "Guardar mais silêncio do que falar: Azeredo Coutinho, Ribeiro dos Santos e a escravidão". In: CARDOSO, José Luis (coord.) Economia Política e os Dilemas do Império Luso-Brasileiro. Lisboa: CNPCDP, 2001; MARQUES, João Pedro. Os Sons do Silêncio: o Portugal de Oitocentos e a Abolição do Tráfico de Escravos. Lisboa: Instituto de Ciências Sociais, 1999, pp.73-9.
} 
Em julho de 2003, ao realizar pesquisas no arquivo e biblioteca do Instituto Histórico e Geográfico Brasileiro (Rio de Janeiro), um dos autores deste estudo - Rafael de Bivar Marquese - encontrou, no fichário de assuntos (item escravidão), uma referência que lhe chamou a atenção. Lá, constava que o Instituto guardava uma Memória sobre o comércio dos escravos escrita por José Carneiro da Silva, $1^{\circ}$ Visconde de Araruama, e publicada em 1838. Especialista no assunto, porém sem jamais ter lido qualquer referência à existência de um texto sobre escravidão redigido por Araruama, solicitou a obra. Tratase de um exemplar fotocopiado, com o nome de José Carneiro da Silva grafado acima dos asteriscos que guardaram o anonimato na folha de rosto. No mesmo dia, após transcrever por completo o documento, dirigiu-se à Biblioteca Nacional. No fichário do setor de Obras Raras, não havia qualquer referência ao opúsculo de Araruama, mas, por outro lado, dentre as obras de Azeredo Coutinho, constava um volume com o mesmo título. Em resumo: os funcionários da Biblioteca Nacional seguiram a mesma atribuição de Sacramento Blake e Rubens Borba de Moraes. Porventura, o contrário pode ter ocorrido: neste caso, Blake obedecera a uma classificação dos bibliotecários do século XIX.

\section{A Memória e o pensamento pró-escravista de Azeredo Coutinho}

Um exame cuidadoso da Memória sobre o comércio dos escravos indica de fato que seu autor não é o bispo José Joaquim da Cunha de Azeredo Coutinho. Para demonstrar isso, convém reagrupar os argumentos da Memória em três tópicos. No primeiro, o autor justifica a continuidade do comércio africano. No segundo, caracteriza a escravidão como fator de sustentação e progresso do Império. No terceiro, desqualifica as ações dos homens engajados na causa antiescravista. À medida que passamos em revista ponto por ponto esses tópicos, podemos cotejá-los com argumentos semelhantes do pensamento do bispo de Olinda.

O princípio que estrutura, na Memória, a justificativa do tráfico negreiro é a oposição entre Civilização e Barbárie. Na África, diz o autor, os negros estão de todo em todo perdidos em guerras e, quando entram na posse de alguns prisioneiros, ou os vendem a terceiros ou os passam "ao fio da espada". Já na América, que notável diferença: trazidos às nações cultas, os cativos são sustentados como "nunca foram em seu país natal" e, de quebra, recebem a graça divina pela doutrina cristã, que os tira do paganismo e os lança no grêmio dos "católicos romanos".

Isso apenas no que diz respeito ao fim soteriológico do tráfico negreiro. Quanto à vida na sociedade, as vantagens não são menores. Principalmente 
digna de nota é a perspectiva de ascensão social, pois os escravos, quando "oficiais peritos", trabalham não só "para seus senhores, como para si”. Noutras palavras, eles amealham algum dinheiro e, com isso, fazem a própria vida, adquirindo bens materiais ou a própria liberdade. "Tenho visto", conta-nos o autor, "escravos senhores de escravos, com plantações, criações de gado vacum e cavalar", assim como, insiste ele, "escravos libertarem-se, tornarem-se grandes proprietários, serem soldados, chegarem a oficiais de patente e servirem outros empregos públicos que são tão úteis ao Estado"6. Por trás do raciocínio do autor, subentende-se que o abrandamento da escravidão se deve à possibilidade de re-inserção social para todos os cativos, desde os escravos-propriedade, passando pelos escravos-proprietários até, como por corolário natural, os escravos libertos - e estes últimos contribuindo para o "esplendor da nação, que os tem naturalizado!” Acresce notar que as perspectivas de ascensão social já estavam institucionalizadas, no Império, pela Constituição de 1824 . O artigo $6^{\circ}$ da Carta outorgada classificava como cidadãos, no tecido social do Império, todos os escravos crioulos que, por si ou por outrem, haviam se tornado libertos: "São cidadãos: os que no Brasil tiverem nascido, quer sejam ingênuos, ou libertos, ainda que o pai seja estrangeiro, uma vez que este não resida por serviço da sua nação."7 Dessa forma, a Memória recupera um dispositivo constitucional brasileiro - concessão da cidadania - para torná-lo princípio de defesa do comércio negreiro.

Os escritos do bispo de Olinda apresentam sensíveis diferenças quando tratam de justificar o tráfico. O primeiro grande contraste é que sua Análise sobre a Justiça do Comércio inscreve-se no gênero filosófico que se ocupa da origem das sociedades e dos contratos sociais - questões fora de conta na Memória. Fundamentalmente, Azeredo Coutinho pretende provar que tanto a escravidão em si como o trato dos escravos não ferem nem violam o direito natural, ainda

\footnotetext{
${ }^{6}$ A experiência familiar de Araruama (provável autor da Memória) bem demonstra a trajetória social ascendente de alguns libertos: na década de 1810, seu cunhado José Antonio de Barcelos Coutinho legou parte considerável de seus vultosos bens a filhos que teve com escravas, todos alforriados na pia batismal. Ver, a respeito, SOARES, Márcio de Sousa. "De pai para filho: legitimação de escravos, herança e ascensão social de forros nos Campos dos Goitacazes, c.1750-c.1830.” Trabalho apresentado ao V Congresso Brasileiro de História Econômica, ABPHE, Caxambu-MG, setembro de 2003, pp.9-15.

${ }^{7}$ Constituição Política do Império do Brasil, Título II, "Dos Cidadãos Brasileiros", Artigo $6^{\circ}$, Parágrafo Primeiro. In: MIRANDA, Jorge. O constitucionalismo liberal lusobrasileiro. Lisboa: CNPCDP, 2001, p.238.
} 
que não sejam conformes a ele. Para o bispo, a escravidão se justifica por ser o direito natural adaptável às circunstâncias: assim como o homem, que a lei natural manda preservar a própria vida, pode decepar um braço enfermo a fim de evitar o pior, assim também a sociedade, que deve preservar a si mesma e a seus membros, pode sacrificar a liberdade e a vida de alguns integrantes em nome da salvação da maioria. ${ }^{8}$ Em Concordância das leis de Portugal, onde se sintetizam algumas das idéias da Análise, a justiça do tráfico também é analisada à luz do direito natural, bem como dos costumes africanos: "as nações da África estavam já acostumadas aos trabalhos da agricultura debaixo de um sol ardente", e "já de tempos antiqüíssimos estavam no costume da escravidão e de venderem os braços que lhes eram pesados, inúteis ou prejudiciais" - costume que "a necessidade do seu maior bem ou do seu menor mal lhes tinha ensinado". ${ }^{9}$ Ao trazê-los para a América, Portugal desonerava a África dos braços ociosos, poupava da morte os guerreiros aprisionados ou os criminosos culpados e os aproveitava em nome da civilização.

As considerações de Azeredo Coutinho sobre o fim soteriológico do tráfico dos africanos são semelhantes às da Memória: "é melhor e mais conforme ao cristianismo deixá-los antes morrer no paganismo e na idolatria do que na nossa santa religião?"10 Com efeito, ambos os autores partilham do antigo pensamento católico português - cujas primeiras formulações remontam à ideologia imperial do século $\mathrm{XV}$, passando pelos textos inacianos a partir da centúria seguinte - sobre o destino das almas dos africanos. ${ }^{11}$ Mas, no que tange ao

\footnotetext{
${ }^{8}$ COUTINHO, Obras econômicas., "Análise sobre a justiça...” p. 248. Ver igualmente os trabalhos citados na nota 5 .

${ }^{9}$ COUTINHO, J. J. da Cunha de Azeredo. Concordância das leis de Portugal e das bulas pontifícias, das quais umas permitem a escravidão dos __ d'África, e outras proibem a escravidão dos índios do Brasil ( $1^{\mathrm{a}}$ ed. 1808). Rio de Janeiro: Arquivo Nacional, 1888, pp. 22-23; Cf. outra justificativa, também de cunho jurídico-filosófico, em que se compara o direito de comprar escravos africanos com o de comprar espólios de guerra em COUTINHO, J. J. da Cunha de Azeredo. Obras Econômicas. "Análise sobre a justiça...”, pp. 267-268.

${ }^{10}$ Cf. COUTINHO, J.J.da Cunha de Azeredo. Obras econômicas. "Análise sobre a justiça...” p. 256, nota de rodapé. O argumento também está presente na Concordância.

${ }^{11}$ Cf. SAUNDERS, A.C.de C.M. História social dos escravos e libertos negros em Portugal (1441-1555). (trad.port.) Lisboa: Imprensa Nacional - Casa da Moeda, 1994, pp.6370; ZERON, Carlos Alberto. La Compagnie de Jésus et l'institution de l'esclavage au Brésil: les justification d'ordre historique,théologique et juridique, et leur integration par une memoire historique (XVIe-XVIIe siècles). Tese de Doutorado. Paris, EHESS, 1998, 2v.; ALENCASTRO, L.F. de. O Trato dos Viventes. Formação do Brasil no Atlântico Sul, séc.XVI-XVII. São Paulo: Companhia das Letras, 2000, pp.155-87.
} 
destino dos corpos, não poderiam ser mais díspares. Retomando o argumento de Turgot, segundo o qual a escravidão se revela racional onde abundam terras e faltam braços, Azeredo Coutinho reputa os escravos necessários para as ocupações de primeira necessidade na América e, por isso, não vê com bons olhos as manumissões nem a ascensão social dos negros: "num país onde as artes e as fábricas são proibidas por causa do monopólio da Metrópole, onde a opinião pública diz que o servir é só para escravos, logo que se tira um braço da agricultura, vai de necessidade aumentar o número de ociosos e vadios, sempre prejudiciais ao Estado, e, por isso, a imperiosa necessidade que manda que numa nação bem regulada se conservem os braços para a agricultura, ainda que comprados, é também a mesma que manda que aqueles que nasceram numa condição escrava não subam arbitrariamente à condição de libertos ociosos". ${ }^{2}$

O segundo tópico da Memória desenvolve-se em torno do princípio de que a escravidão escora a civilização, estimula o comércio e produz a riqueza de certos países. Em complementação ao tópico anterior, de que as nações civilizadas são benéficas para os negros, agora os negros é que são benéficos para as nações civilizadas. "Sem a escravatura, o que seria n’ América o seu comércio de exportação!” Imprescindível para a extração das minas, o trabalho escravo ainda é imperativo para o cultivo da lavoura, "única coisa capaz de fazer o Brasil chegar a uma categoria que nenhum reino ou império lhe poderá igualar." Por fim, a Memória ainda argumenta que os escravos são responsáveis pela "maior parte da tripulação de nossas embarcações de cabotagem, que abastecessem as nossas cidades marítimas dos efeitos das outras províncias". Importa notar que, nessas passagens, o Brasil é tido por unidade política autônoma e independente, cujo abastecimento das cidades marítimas opera-se por um comércio interprovincial como que auto-suficiente.

Azeredo Coutinho revela-se novamente distante do campo semântico em que se estrutura a Memória. Falecido em Portugal, em 1821, dois dias antes de tomar posse nas Cortes de Lisboa como deputado pela Província do Rio de Janeiro $^{13}$, Coutinho centra seus escritos no exame do sistema colonial portu-

\footnotetext{
${ }^{12}$ Cf. COUTINHO, J.J.da Cunha de Azeredo. Obras econômicas. "Análise sobre a justiça...”, p. 286.

${ }^{13}$ Cf. BERBEL, Márcia Regina. A nação como artefato. Deputados do Brasil das Cortes Portuguesas, 1821-1822.São Paulo: Hucitec, 1999, pp.70-1.
} 
guês, que, por essa razão, não mencionam as benesses proporcionadas pela escravidão senão referindo-se, em globo, a Portugal e ao Brasil. A metrópole, cuja produção "não chega para pagar o débito do seu absolutamente necessário, não tem outro supérfluo para o seu grande comércio da Europa mais do que as produções da agricultura das suas dilatadíssimas colônias, principalmente do Brasil". Sem o sistema escravista, "como poderia Portugal subsistir"? O país se veria "sem artes, sem comércio, sem luxo, em um estado propriamente das nações bárbaras e escravas." ${ }^{14}$ Aqui, o Brasil não é reputado como unidade política, mas antes como parte de um sistema cujo colapso levaria à bancarrota da metrópole. Por fim, como já o dissemos, Coutinho julga que o trabalho escravo africano deve ser rigorosamente aplicado nas necessidades mais prementes da colônia. Advoga, por isso, que os negros - "aqueles braços feitos mais para um trabalho contínuo no meio dos ardores do Sol do que para os frios das águas" não deveriam servir na marinhagem, onde seriam com muito maior proveito substituídos pelos índios domesticados. ${ }^{15}$ Em Discurso sobre o estado atual das minas do Brasil (1804), lamentava que os braços africanos se desviassem da agricultura para ser sugados pela alta mortalidade das minas. ${ }^{16}$ Nada mais oposto ao arrazoado expendido no documento de 1838.

Finalmente, no terceiro tópico da Memória sobre o comércio dos escravos, o autor desfere críticas virulentas contra os que pugnavam pelo fim do tráfico negreiro. Mas, ainda aqui, sua perspectiva distancia-se daquela de Azeredo Coutinho. O documento de 1838 impreca os filantropos de conspirarem contra a riqueza a que o Brasil pode chegar por meio do sistema escravista: "Muitos destes governos não querem escravos no Brasil, porque calculam de antemão e vêm que futuro brilhante espera o Brasil”. Segundo a Memória, à capa do discurso humanista subjazem interesses econômicos e imperialistas que desejam obstar à marcha do progresso brasileiro boicotando-lhe os braços africanos. Embora Azeredo Coutinho também julgue que os filantropos sejam ardilosos, encobertos e astutos, os motivos que os movem são o desejo

${ }^{14}$ Cf. COUTINHO, J.J.da Cunha de Azeredo. Obras econômicas. "Análise sobre a justiça...", p. 284-5.

${ }^{15}$ Cf. COUTINHO, J.J.da Cunha de Azeredo. Obras econômicas. "Ensaio econômico...”, p. 100. ${ }^{16}$ Cf. COUTINHO, J.J.da Cunha de Azeredo. Obras econômicas. "Discurso sobre o estado atual das minas no Brasil”, pp. 201-202. 
e a ambição de solapar o Antigo Regime: "debaixo do pretexto de defender os direitos quiméricos da liberdade e da humanidade, [os antiescravistas] se têm mostrado inimigos dos tronos e da religião", negando "obediência aos soberanos" e "armando os seus mesmos concidadãos uns contra os outros". ${ }^{17} \mathrm{O}$ bispo aproxima-se da Memória apenas numa nota escrita em 1811 para o Ensaio econômico sobre o comércio de Portugal com suas colônias, em que reproduz argumentos produzidos na França: "hoje, dizem os mais sensatos da França que os ingleses, debaixo da máscara da humanidade, querem fazer-se senhores de todos os braços dos negros da África para cultivarem as muitas terras e possessões que já têm na Serra Leoa." ${ }^{18}$ Ainda assim, essa crítica é incipiente e pouco desenvolvida, quando comparada com a da Memória, onde se transforma em teoria conspiratória contra o nascimento de um poderoso Império.

Noutras palavras, enquanto nas reflexões de Azeredo Coutinho a hipocrisia dos filantropos aparece, sobretudo, como um golpe contra o Absolutismo e a boa ordem social, na Memória sobre comércio dos escravos a hipocrisia dos humanistas é apenas uma lança com que ferir de morte a economia de um futuro grandioso Império. E não é difícil apontar a razão para tais diferenças: até a data de publicação das obras de Azeredo Coutinho, o Império português não havia sido pressionado a dar um fim no tráfico de africanos, e os principais corolários dos novos tempos que ameaçavam pairar sobre as possessões portuguesas eram o da ruptura com o Antigo Regime e o da instalação de um regime representativo. À medida que as pressões diplomáticas inglesas se fizeram sentir a partir de 1810 - e isso explica a nota que Coutinho aditou em 1811 ao seu Ensaio, originalmente de 1794 -, a recepção luso-brasileira alterou-se gradualmente. Depois do Tratado de 1826, que abolia definitivamente o tráfico, as línguas brasileiras mais viperinas já não hesitavam em envenenar o movimento antiescravista, maculando-o com a pecha de interesseiro, comezinho e arrivista.

\footnotetext{
${ }^{17}$ COUTINHO, J. J. da Cunha de Azeredo. Concordância das leis de Portugal e das Bulas Pontifícias, p. 17; cf. tb. Obras econômicas. "Análise sobre a justiça...", p. 237.

${ }^{18}$ COUTINHO. J.J. da Cunha de Azeredo. Obras econômicas. "Ensaio econômico...", p. 145 , nota "a".
} 


\section{A Memória e a política da escravidão}

De fato, o conteúdo da Memória sobre o comércio dos escravos dialoga intimamente com a conjuntura do sistema escravista brasileiro após 1835 e com o discurso instaurado em meados da década de 1830 pelo grupo conservador do Regresso, cuja figura mais proeminente foi Bernardo Pereira de Vasconcelos. Como se sabe, o trato negreiro foi interdito ao Brasil pela convenção assinada com a Inglaterra em 1826 e posta em execução em 13 de março de 1830. Para os parlamentares brasileiros, o tratado era algo vexatório por dar a ver que a proibição tinha sido imposta de fora para dentro, por criar um tribunal estrangeiro para julgar súditos brasileiros e por tipificar crimes jurídicos fora do âmbito da Assembléia nacional. Como o Executivo, hipertrofiado, desrespeitara a soberania dos representantes nacionais da Câmara e do Senado, uma lei nacional deveria ser imediatamente aprovada para elevar as intenções brasileiras à esfera dos compromissos filantrópicos assumidos no exterior e, o que é mais, para reafirmar a preeminência do Legislativo sobre o Executivo no que tocava à política externa. Não por acaso, começaram os trabalhos parlamentares a elaborar a nova lei apenas um mês depois da deposição de D. Pedro I, em abril de $1831 .{ }^{19}$

A lei de 7 de Novembro de 1831, como viria a ser chamada, foi, pois, aprovada no contexto de radicalização do espírito liberal da "Revolução de Sete de Abril". Pouco mais de 10 anos após sua aprovação, deputados ainda se referiam a ela como fruto de "um tempo, e esse tempo data da proclamação do sistema constitucional, em que passava em moda ser inimigo do tráfico de africanos e que até não se podia ter a reputação de homem liberal, de homem filósofo, sem ser inimigo desse tráfico". ${ }^{20}$ Ainda no contexto do Sete de Abril, figuras de proa como Evaristo da Veiga propunham concursos para a publicação de memórias sobre o fim do comércio negreiro, e ministros importantes como Alves Branco chegaram a assinar artigos adicionais com a Inglaterra

\footnotetext{
${ }^{19}$ Anais do Parlamento Brasileiro - Câmara dos Srs. Deputados [Coligidos por Antonio Pereira Pinto]. Rio de Janeiro, Tipographia de H. J. Pinto, 1878, 13 de maio de 1831, p. 29. Doravante citados como ACD. Anais do Senado do Império do Brasil [coletor anônimo]. Rio de Janeiro, s. editora, 1914, 31 de maio de 1831, p. 254. Doravante citados como AS. ${ }^{20}$ ACD, 1844, 14 de maio, pp. 106-7. A fala é do deputado Saturnino de Souza Oliveira.
} 
com vistas a recrudescer as medidas antitráfico. ${ }^{21}$ Desnecessário lembrar que a Rebelião dos Malês, em 1835, esporeou alguns liberais com pensamentos radicalizados e até permitiu que fosse enviada à Corte do Rio de Janeiro uma "Representação" da Assembléia Legislativa Provincial da Bahia pedindo o fim imediato do comércio ilícito de africanos. ${ }^{22}$

Por outro lado, a maioria dos Liberais Moderados dava outro sentido ao dia 7 de Novembro de 1831. Uma vez reafirmados, com a mera aprovação da lei, os desígnios liberais da Assembléia, assim como a soberania nacional, não seria preciso extremar nenhuma política antiescravista para levar às últimas conseqüências as disposições abolicionistas. Durante os debates que aprovaram a lei de 7 de Novembro, os parlamentares reduziram em $85 \%$ os prêmios para os delatores do tráfico ilícito e derrubaram todas as propostas de libertação dos escravos contrabandeados entre março de 1830 (início do tratado anglo-brasileiro) e novembro de 1831 (início da aplicação da nova lei). ${ }^{23}$

Estabeleceu-se, por assim dizer, uma espécie de "pacto do silêncio" nos debates parlamentares após a aprovação da lei de 1831: quem era conivente ao tráfico, não dizia nada, apoiando-o na prática; quem era contrário, enviava projetos para aperfeiçoar a lei, mas via suas propostas invariavelmente deixadas de lado. Dessa forma, o tráfico de escravos foi gradualmente recuperando seu volume. A soma de africanos ilegalmente introduzidos no Império passou de 1889, em 1834, para 4427, em 1835. No ano seguinte, saltou para 14574. Mais impressionante ainda é a escalada a partir de 1837: 41002 nesse ano, 46976 em 1838 e em 1839, finalmente, 61170 - um volume assustador. ${ }^{24}$ Afinal, o que aconteceu de 1837 em diante?

O grupo dos Liberais Moderados comprometidos com o Sete de Abril seguiu relativamente coeso até 1834 e a aprovação do Ato Adicional, quando Diogo Antonio Feijó e Evaristo da Veiga concorreram às eleições para Regente contra a candidatura de Honório Hermeto Carneiro Leão e Bernardo

\footnotetext{
${ }^{21}$ PINTO, Antônio Pereira. Apontamentos para o direito internacional ou collecção completa dos histórica e documentada sobre as Convenções mais importantes. Rio de Janeiro: F. L. Pinto \& Cia. - Livreiros Editores, 1866, v. 1, pp. 394-398.

${ }^{22}$ Cf. REIS, João José. Rebelião escrava no Brasil, p.528.

${ }^{23}$ ACS, 15 de junho de 1831, pp. 374-5; 16 de junho, pp. 378-9; ACD, 19 de outubro, p. 238. ${ }^{24}$ ELTIS, David; BEHRENDT, Stephen; RICHARDSON, David; e HERBERT, S. Klein. The Trans-Atlantic Slave Trade: A Database on CD-ROM. Cambridge: Cambridge University Press, 1999.
} 
Pereira de Vasconcelos. Após a derrota eleitoral, Vasconcelos e seu grupo aprofundaram a dissensão no seio dos Liberais Moderados e fundaram o Regresso, cuja principal pauta política era a reinterpretação do Ato Adicional e a revisão do ideário liberal da "Revolução de Sete de Abril". No que diz respeito ao comércio de africanos, Vasconcelos começou a romper com a tendência dos Liberais Moderados - silenciar-se quando a favor do tráfico, propor reformas quando contrário a ele - e, no Parlamento mesmo, iniciou uma campanha aberta pela retomada do tráfico e pela revogação da lei de 1831. Foi ele o primeiro deputado que propôs a revogação da lei, em $1835 .{ }^{25}$ No ano seguinte, voltaria a aventar a ab-rogação dos seus primeiros seis artigos, dizendo que eram a fonte do "prejuízo moral e do interesse público e particular". Segundo Vasconcelos, tais artigos oprimiam os proprietários por lhes retirar a segurança jurídica sobre a propriedade adquirida, uma vez que os escravos africanos introduzidos às escondidas no Império eram declarados livres e suscetíveis de alienação:

"há de mostrar que esta lei de 1831, isto é, os seus seis primeiros artigos só servem para opressão dos cidadãos e interesse de alguns especuladores sem consciência [...]; que um dos artigos cuja revogação propõe autoriza a qualquer pessoa para prender a todo africano, sem mandado especial da autoridade, do que tem resultado graves inconvenientes e muitos vexames a imensas pessoas [...]. Lê-se somente o seguinte projeto do ilustre deputado: 'A Assembléia Legislativa Provincial decreta: Artigo único. São revogados os primeiros seis artigos da lei de 7 de Novembro de 1831, que declarou livres os africanos importados no Brasil". ${ }^{26}$

Em 1837, Vasconcelos volta à cena para lamentar que o projeto - que é “o seu mimoso" - não tinha recebido atenção da Casa. ${ }^{27}$ No mesmo ano, Caldeira Brant inicia no Senado a apresentação de um projeto formalmente bem acabado com o objetivo de substituir a lei de 1831. No texto do projeto, cada um dos pontos apresentados por Vasconcelos volta a aparecer: onde a lei de 1831 declara livres os africanos introduzidos no Império, o projeto não o faz;

\footnotetext{
${ }^{25}$ ACD, 24 de julho, 1835, p. 109.

${ }^{26}$ ACD, 25 de junho, 1836, p. 224.

${ }^{27}$ ACD, 17 de junho, 1837, p. 272.
} 
onde a lei de 1831 impõe pena também sobre os proprietários que participassem do desembarque de africanos, o projeto os reputa apenas cúmplices; onde a lei de 1831 permite que os proprietários sejam denunciados por qualquer pessoa e seus cativos sejam aprisionados, o projeto restringe tais faculdades a denúncias feitas acerca de escravos que ainda se encontram no litoral, mas jamais nas fazendas dos proprietários. ${ }^{28}$

A articulação em torno da atitude de Vasconcelos se fez rapidamente perceber, pois muitos ataques à lei de 1831 partiram também da sociedade civil. De 1836 a 1839, a Assembléia Legislativa Geral se viu às voltas com pelo menos nove representações provinciais ou municipais que postulavam a pura supressão da fatídica lei ou a alteração de alguns de seus termos. As invectivas foram escritas pelas câmaras municipais de Valença, Vassouras e Paraíba do Sul - coração da cafeicultura na Província do Rio de Janeiro, em processo de franca expansão desde a década anterior - , assim como pelas assembléias provinciais de São Paulo, Rio de Janeiro, Minas Gerais e Bahia. Em 1839 e 1840, a câmara recebeu duas representações de Minas e outras duas da Bahia nas quais a pauta dos conservadores era expressamente reivindicada: reforma do código do processo e do código criminal, além da revogação da lei de $1831 .^{29}$

O que se percebe é que o grupo capitaneado por Bernardo Pereira de Vasconcelos conseguiu rápido apoio político de importantes câmaras municipais e assembléias provinciais do Império, e, com certeza, a defesa pública da escravidão contribuiu significativamente para isso. Em 1840, Montezuma não se conformava com o surgimento e a rápida consolidação do Regresso na Câmara, atribuindo ao fenômeno a defesa da reabertura do tráfico: "Antes de 19 de Setembro, toda a Câmara se recordará de que se fazia da lei de 7 de Novembro e deste projeto que veio do Senado uma alavanca política para, por este meio, se tirar da urna eleitoral aqueles que se haviam declarado contra a lei [o projeto de 1837] do Senado. [...] O partido que subiu ao poder em $19 \mathrm{de}$ Setembro, é uma verdade constante, fez disso sua alavanca política; e podese mesmo asseverar que prometeu, por assim dizer...sim! prometeu que essa lei havia de ser revogada, que a lei do Senado havia de passar. Um membro influente, o mais influente nesse gabinete [Vasconcelos], nesta casa apresen-

\footnotetext{
${ }^{28}$ ACS, 30 de junho, 1837, pp. 175-181.

${ }^{29}$ ACD, 4 de setembro de 1839, p. 36; ACS, 14 de abril de 1840, p. 12.
} 
tou um projeto simples, e peremptoriamente revogando a lei de 7 de Novembro, sem ao menos apresentar algumas medidas salutares que fossem encobrir de uma revogação de tal natureza." ${ }^{30}$ Além dos resultados eleitorais, acresce lembrar que a campanha do grupo conservador coincide pontualmente com a retomada do trato negreiro a níveis superiores aos do decênio de 1820, quando o comércio era lícito. A tendência predominante dos Liberais Moderados entre 1831 e 1835 - a de silenciar-se sobre o tráfico quem era por ele favorável e a de criticá-lo quem era a ele contrário - inverte-se no grupo conservador entre 1836 e 1839: critica a lei de 1831 quem se engaja no tráfico ou se interessa por ele, cala-se quem lhe faria reservas.

É possível denominar esse entrosamento descrito acima de política da escravidão. Oposta à atitude dos liberais do Sete de Abril -, que eram pela maior parte coniventes com o tráfico e lutavam para preservá-lo, mas não abandonavam o campo discursivo filantrópico e emancipacionista de 1831 - a política da escravidão dos conservadores tinha como fundamento a defesa pública do tráfico e dos proprietários como estratégia de amealhar apoio político entre variados grupos economicamente importantes do Império. ${ }^{31}$ A Memória sobre o comércio de escravos, publicada em 1838, enquadra-se perfeitamente nessa nova tendência: seu autor, favorável à continuação do tráfico, argumenta publicamente a seu favor. Mais do que isso: o próprio conteúdo da memória relaciona-se com o repertório utilizado pelos defensores do tráfico depois de 1836.

Como já vimos, a Memória retrata a escravidão como elemento constitutivo da civilização e do progresso do Império brasileiro, que, graças ao trabalho dos cativos, "pode estender a sua cabeça para a África, a sua mão direita para a Ásia, a esquerda para a Europa e o resto do corpo por toda a América". "Quando o Brasil, porém, contar em seu seio uma população correspondente a seu território", afirma o autor da Memória, "então, digo eu, também, este comércio deve ser abolido". A noção de que o Império se escora no sistema escravista encontra-se igualmente numa "Representação" enviada à Câmara dos Deputados em 1839 pela Assembléia de Minas Gerais. Convencida que estava "dos justos clamores que em toda esta província se levantam contra a lei de 7 de Novembro de 1831", a Assembléia julgava intempestiva a "proibição do tráfico de escravos, cujos braços são ainda indispensáveis à conserva-

${ }^{30}$ ACD, 23 de junho de 1840, pp. 854-5. 
ção e progresso de sua Agricultura e Mineração". As principais atividades econômicas da Província - "e quiçá [de] todo o Império" - vão necessitar "ainda por longo tempo do trabalho dos escravos" enquanto for o "Solo carecido de suficiente população". ${ }^{32}$ Acresce lembrar que a fala de Bernardo Pereira de Vasconcelos - de que a África civiliza o Brasil - proferida no Parlamento na década de 1840 não é senão uma bem formulada sentença cujos pressupostos pertencem ao mesmo discurso pró-escravista que se estabeleceu no Império a partir de 1836.

O lugar-comum que acusa na filantropia de outros Estados interesses econômicos não aparece na Memória por acaso. Desde 1838, quando acabou com a escravidão no próprio Império britânico, o movimento abolicionista inglês havia depositado todas as suas fichas na supressão do tráfico atlântico alhures. ${ }^{33}$ No Brasil, o embaixador britânico Hamilton instou uma dezena de vezes pela ratificação dos artigos adicionais de 1835, que conferiam aos vasos britânicos maior poder para capturar tumbeiros. ${ }^{34}$ Para espanto dos brasileiros, Portugal teve de aceitar em 1839 o bill Palmerston, que foi por lá o equivalente do bill Aberdeen de 1845 por aqui. Depois do Equipment Act de 1839 e do crescente número de apreensões de navios brasileiros, a acusação presente na Memória torna-se verdadeiro bordão retórico e se espalha pelas bocas dos mais variados deputados na década de 1840. O conservador Carneiro da Cunha, por exemplo, confessa em 1843: "Não creio na amizade dos ingleses para conosco; os ingleses querem destruir a única indústria que temos no Brasil, qual é a agricultura; eles viram muito

\footnotetext{
${ }^{31}$ O historiador William Cooper Jr. cunhou o termo "política da escravidão" para designar o conjunto de valores e práticas que direcionava os eleitores sulistas dos EUA a escolher apenas candidatos que não pusessem em questão, na esfera das discussões nacionais, a existência do sistema escravista. COOPER Jr., William. Liberty and slavery - southern politics to 1860 ( $1^{\mathrm{a}}$ ed., 1983). Columbia, University of South Caroline Press, 2000. O termo pode ser aplicado ao período da Regência, feitas algumas modificações semânticas: aqui, designaria não o conjunto de práticas políticas do eleitorado, mas sim de um grupo político (o conservador) que se servia, na esfera pública, da crítica à lei de 1831e da defesa dos interesses escravistas para fundamentar uma estratégia de cooptação de importantes grupos econômicos do Império. Nesse sentido, não bastaria ser simplesmente conivente com o tráfico negreiro - o que, de resto, ocorreu desde o primeiro dia após a aprovação da lei de 1831 -, senão lutar, na imprensa e no Parlamento, pela sua preservação.

${ }^{32}$ Arquivo da Câmara dos Deputados: Ano 1839/Lata 126/Maço 11/Pasta 4.

${ }^{33}$ Cf. TEMPERLEY, Howard. British antislavery: 1833-1870. London: Longman, 1972.

${ }^{34}$ Cf. BETHELL, Leslie. A Abolição do tráfico de escravos no Brasil, p. 122.
} 
bem que, tirando-nos os braços, não podia continuar a agricultura; não querem, portanto, que sejamos agricultores, que sejamos industriosos." E logo em seguida adita: "Fala-se em filantropia inglesa, fala-se em um tratado a respeito do tráfico de escravatura, quando se conhece que, sob esse pretexto de humanidade, a Inglaterra quer proteger os seus interesses coloniais." ${ }^{35}$

\section{José Carneiro da Silva, o Partido Conservador e a política da escravidão}

Não apenas o discurso da Memória e o momento de sua produção se enquadram na conjuntura de formação e consolidação do Partido Conservador, entre 1836 e 1839, mas também a própria trajetória biográfica de seu provável autor, José Carneiro da Silva, $1^{\circ}$ Visconde de Araruama - cuja genealogia ascendente e descendente segue o curso de muitas outras famílias que se envolveram de perto com o estabelecimento da corte no Rio de Janeiro em 1808 e, anos mais tarde, com o projeto de Estado dos saquaremas ${ }^{36}$.

Como é sabido, após a chegada da família bragantina na capital da colônia, regiões dos arredores como Minas Gerais, São Paulo e Bacia de Campos adquirem proeminência política e comercial por força das trocas interprovinciais, do abastecimento à capital e das produções para o exterior. ${ }^{37}$ Como diz o pró-

\footnotetext{
${ }_{35}$ ACD, 6 de fevereiro de 1843, pp. 542-3. O topos da crítica aos interesses imperiais ingleses na defesa do tráfico negreiro para o Brasil nasceu já em 1811, ano das primeiras apreensões de negreiros brasileiros na Costa da Mina. Afora a nota de Azeredo Coutinho citada acima, vale lembrar o ofício que D.Rodrigo de Souza Coutinho endereçou ao rei Jorge III, e que se encontra reproduzido em VERGER, Pierre. Fluxo e refluxo do tráfico de escravos entre o Golfo de Benin e a Bahia de Todos os Santos, dos séculos XVII a XIX. (trad.port.) São Paulo: Corrupio, 1987, pp.301-2.

${ }^{36}$ Ilmar Mattos, por exemplo, cita expressamente Araruama como um dos membros da nova classe senhorial que se formou no Centro-Sul do Império do Brasil na primeira metade do século XIX. Ver seu Tempo Saquarema, p.42.

${ }^{37}$ Cf. DIAS, Maria Odila Silva. “A Interiorização da Metrópole (1808-1853).” In: MOTA, Carlos Guilherme. (org.) 1822: Dimensões. São Paulo: Perspectiva, 1972; LENHARO, Alcir. As tropas da moderação. O abastecimento da Corte na formação política do Brasil: 1808-1842 [1 ${ }^{\mathrm{a} e d .:}$ 1979]. Rio de Janeiro: Secretaria Municipal de Cultura, Turismo e Esportes, Depto. Geral de Documentação e Informação Cultural, Divisão de Editoração, 1993; MARTINHO, Lenira Menezes \& GORESTEIN, Riva. Negociantes e Caixeiros na Sociedade da Independência. Rio de Janeiro: Secretaria Municipal de Cultura, Turismo e Esportes, Depto. Geral de Documentação e Informação Cultural, Divisão de Editoração, 1993; OLIVEIRA, Cecilia Helena L. de Salles. A Astúcia Liberal. Relações de mercado e projetos políticos no Rio de Janeiro (1820-1824). Bragança Paulista: Edusf-Ícone, 1999.
} 
prio José Carneiro da Silva, onze anos depois da chegada da família real, as transações de Campos dos Goitacases com outras áreas brasileiras são intensas: de Minas recebe couros, gados, toucinhos e carnes de porco; da Bahia, tecidos, louças e cocos; de Espírito Santo, panos de algodão e colchas; do Rio Grande do Sul, carnes e sebo etc. Entretanto, "com a Cidade do Rio de Janeiro é que faz o seu maior Comércio, para ela envia os seus gêneros e em troca recebe de todos aqueles que vêm da Europa. Fazendas de lã, algodão, sedas, galões, vinhos, vinagres, azeites, cerveja, aguardente, presuntos, paios, sal, louças, trigos, couros curtidos, ferragens, em uma palavra, tudo o que é necessário para a comodidade da vida, para o luxo e para o prazer." ${ }^{38}$ Esse entrosamento comercial, que cedo se traduz na realização de obras infra-estruturais - por ordem de D. João VI, abre-se uma estrada entre a região e a província mineira, e José Carneiro da Silva pede que secassem parcialmente a Lagoa Feia para encurtar o caminho entre a Vila de S. Salvador, futuro município de Campos, e o Rio de Janeiro -, não tardará em cimentar o comprometimento político que assumirão as famílias locais com a construção do novo aparelho estatal, quer na época da independência, quer na deposição de D. Pedro I em 1831.

Entre os potentados familiares do norte fluminense que se aproximam da formação do novo Estado, é de grande relevo a velha estirpe dos Carneiro da Silva, cujos ascendentes remontam ao século XVII ${ }^{39}$, mas cuja política matrimonial a liga com ramos mais recentes, como os Ribeiro de Castro, os Neto Cruz e os Neto dos Reis. ${ }^{40}$ Inicialmente engajada na criação de gado, a família Carneiro da Silva fundou seu primeiro engenho de açúcar em 1798, em Quissamã, distrito de Macaé, na esteira da crise da produção açucareira mundial provocada pela Revolução de São Domingos. Em 1819, João Carneiro da Silva lança a sua Memória topographica e historica sobre os Campos dos Goitacazes, empenha-

\footnotetext{
${ }^{38}$ SILVA, José Carneiro da. Memória topographica e historica sobre os campos dos goitacazes, com huma noticia breve de suas producções e commercio offerecida ao muito poderoso Rey e senhor nossos D. João VI por um natural do mesmo paiz. Rio de Janeiro, Impressão Régia, 1819, p. 52.

${ }^{39}$ MARIANI, Alayde Vanderlei. "Quissamã, história e sociedade”. In: MARCHIORI, M.E.P. et alli. Quissamã. Rio de Janeiro: SPHAN-Fundação Nacional Pró-Memória, 1987, pp. 30-31. Agradecemos a Marina de Mello e Souza a indicação desta referência.

${ }^{40}$ Cf. PANG, Eul-Soo. In Persuit of Honor and Power: Noblemen of the Southern Cross in Nineteenth-century Brazil. Tuscaloosa and London: The University of Alabama Press, 1988, pp. 85-89.
} 
se na abertura de novos caminhos comerciais pelo hinterland fluminense e já é tenente-coronel. Em breve, lutaria pela independência brasileira e, anos mais tarde, atuaria como deputado na Assembléia Legislativa Provincial do Rio de Janeiro, onde hasteará a bandeira do Partido Conservador.

Como aponta Jeffrey Needell, o principal apoio político ao grupo do Regresso no final da década de 1830 provém, sobretudo, das famílias aristocratas e dos produtores de açúcar que tinham engenhos encravados nas zonas baixas da província fluminense - caso da família Carneiro da Silva. A subscrição das propostas conservadoras - que incluem a crítica aberta à lei de 1831 - se faz sentir inclusive na Assembléia Legislativa Provincial do Rio de Janeiro: já na primeira legislatura, de 1836 a 1837, 30 dos 75 deputados eleitos alinham-se com o recém-articulado grupo conservador; na legislatura seguinte, de 1838 a 1839, os deputados do Regresso representam 50\% da casa. Não é, pois, de admirar que logo na primeira legislatura uma comissão liderada por José Clemente Pereira, outro medalhão dos conservadores, emite juízo em desfavor da lei de 1831. No ano seguinte, a segunda legislatura endereça à Assembléia Geral representação pedindo a revogação da lei de $1831 .^{41}$

Cumpre acrescentar ainda um último ponto de convergência. À medida que os conservadores se consolidam na organização do Estado brasileiro, a carreira nobiliárquica de Carneiro da Silva dispara. Em 1841, torna-se Fidalgo Cavaleiro; em 1844, $1^{\circ}$ Barão de Araruama e, três anos mais tarde, $1^{\circ}$ Visconde com honras de grandeza de Araruama. Títulos que apenas confirmam a maneira íntima como José Carneiro da Silva privou com a alta corte bragantina e sua burocracia político-administrativa. Mattoso Maia, em discurso necrológico ao Visconde, falecido em 1864, dizia que a "sua fazenda de Quissamã tinha sido visitada por pessoa da mais alta categoria, tais como o falecido bispo do Rio de Janeiro, ministros de estado, presidentes de província etc., e tanto dos grandes da terra como dos pequenos não podia deixar de cativar as simpatias gerais". ${ }^{42}$ Com efeito, a fazenda de Quissamã, além de ter recebido Victor Frond e Charles Ribeyrolles, que ajudaram a gravar sua imagem para os con-

\footnotetext{
${ }^{41}$ Cf. NEEDELL, Jeffrey D. "Party Formation and State-Making: The Conservative Party and the Reconstruction of the Brazilian State, 1831-1840". In Hispanic American Historical Review, vol. 81(2): 259-308, May 2001, p. 297, p.289.

${ }^{42}$ Almanak administrativo, mercantil e industrial da corte e província do Rio de Janeiro para o ano de 1865. Rio de Janeiro, Eduardo \& Henrique Laemmert, 1865, seção "Almanak - necrológio das Casas Titulares", p. 50.
} 
temporâneos e para a historiografia do século XX, chegou a acomodar a comitiva imperial de D. Pedro II, que resolvera ver pessoalmente os melhoramentos materiais ao norte da província do Rio de Janeiro. ${ }^{43}$ À morte do Visconde sobreviveu sua orientação conservadora no filho Bento Carneiro da Silva (chefe regional do Partido Conservador) e no genro Almeida Pereira Filho, que chegou a ser ministro dos Negócios do Império em $1861 .^{44}$

Em face de sua trajetória biográfica, parece bastante plausível que José Carneiro da Silva tenha sido o autor da Memória sobre o comércio dos escravos. Essa atribuição já foi feita de fato no próprio século XIX, apenas dois anos depois da morte do Visconde ${ }^{45}$. De resto, tal opinião foi algumas vezes endossada no século passado. Na década de 1940, a Grande Enciclopédia Portuguesa e Brasileira diz que a José Carneiro da Silva são devidas a "notável Memória topográfica sobre o campo dos Goytacazes, 1819, e outra, notável

${ }^{43}$ Cf. MARIANI, A. V., op. cit., pp. 35 e 41; BARATA, Carlos Eduardo de Almeida \& BUENO, Antônio Henrique da Cunha. Dicionário das Famílias Brasileiras. São Paulo: Terra Editora, 2001, v. I, p. 657. Sobre sua visita a Quissamã, escreveu Ribeyrolles: “o acolhimento fidalgo que se presta ao estrangeiro nessa grande e antiga casa, onde a hospitalidade é costume de séculos, a simplicidade verdadeiramente nobre do anfitrião e a cordialidade liberal de seus filhos permitiram-nos tudo ver, tudo examinar com detalhe, desde os trabalhos dos campos até às especialidades das usinas, das oficinas e seus aparelhamentos. Vimos aí uma máquina de procedência inglesa que aciona três cilindros horizontais. A engrenagem é simples e segura, a peça fortemente instalada, a rotação de grande força. Pode-se movê-la com rapidez em caso de necessidade. Para a distilação da aguardente de cana completa o sistema um alambique a vapor, aparelho que se encontra nos sete estabelecimentos açucareiros que se grupam, num raio de algumas léguas, em torno da fazenda matriz". Brasil Pitoresco. ( $1^{\text {a }}$ ed: 1859; trad.port.) São Paulo: MartinsMEC, 1976, 2v, v.2, pp.18-9. As litogravuras sobre o trabalho escravo em Quissamã, compostas a partir de fotografias de Frond, constituem uma das séries de imagens sobre a escravidão brasileira mais utilizadas pelos historiadores e mesmo pelos livros didáticos voltados ao Ensino Fundamental e Médio. Para um exemplo recente de uso das litogravuras da propriedade de Araruama, ver SLENES, Robert W. Na Senzala, uma Flor. Esperanças e recordações na formação da família escrava - Brasil Sudeste, século XIX. Rio de Janeiro: Nova Fronteira, 1999, p.153 e 155.

${ }^{44}$ Cf. MARIANI, A. V., op. cit., p. 41.

${ }^{45} \mathrm{Cf}$. Histoire Générale des Hommes Vivants et des Hommes Morts dans le XIXe siècle, dont les fonctions, les ouevres et les positions sociales peuvent être representees d'apres des documents officiels, des memoires, des manifestes et d'autres écrits recueillis ou indioques dans les archieves de lá ouevre, par des ecrivans de diverses nations. Tome Deuxième, de l'edition ou les articles se classent dans l'ordre alphabetique par Tome. Genève, A la direction de l'Histoire Generale, 1860-1866, extrato incluído na pasta 6, lata 3, da coleção "Titulares do Império", arquivo do IHGB. 
também, sobre a escravatura" ${ }^{46}$ Por fim, nos anos oitenta, dois estudos ainda atribuem a autoria da memória a Araruama - José Ivan Calou Filho, em sua "Introdução" à Concordância das Leis de Portugal e das Bulas Pontifícias, e Alayde Vanderlei Mariani, em estudo sobre a vida dos proprietários do Engenho de Quissamã. Todas essa imputações acabam, pois, por corroborar a hipótese de que o opúsculo foi composto pelo Visconde.

\section{0 anonimato}

Lançada em 1838, a Memória não poderia ser uma republicação dos escritos de Azeredo Coutinho. Ainda que respeitado pela produção intelectual, o bispo de Olinda era visto com reservas pelos liberais brasileiros por causa dos escritos absolutistas em que invectivou tão vivamente o sistema representativo. Citá-lo ou republicá-lo na década de 1830 era como que revivificar o Antigo Regime em plena monarquia constitucional - risco que nenhum dos partidos políticos queria correr, muito menos os conservadores, cujas propostas de centralização jurídico-administrativa e cujo apoio adquirido entre os antigos restauracionistas na cidade do Rio de Janeiro apresentavam certo ressaibo de déjà vu aos liberais moderados. ${ }^{47}$ Isso é tanto mais manifesto quanto um dos autores citados na Memória é justamente Charles Theremin, defensor do ideário escravista e, ao mesmo tempo, advogado do regime representativo - portanto, um autor perfeitamente autorizado para as elites liberais e escravistas da Regência. ${ }^{48}$

\footnotetext{
${ }^{46}$ Grande Enciclopédia Portuguesa e Brasileira - ilustrada com cerca de 15.000 gravuras e 400 estampas a cores. Rio de Janeiro, Editorial Enciclopédia Ilimitada, v. III, 194(?), p. 84.

${ }^{47}$ A respeito do apoio aos conservadores pelos antigos restauracionistas, ver NEEDELL, J., "Party Formation", pp. 283-286.

${ }^{48}$ Cf. THEREMIN, Charles. De l'état présent de l'Europe et de l'accord entre la légitimité et le sistème représentatif [ $1^{\mathrm{a} e d}$., 1816]. Edição fac-similar sem indicação de cidade. Elibron Classics, 2003. Desacreditando o aspecto radical da Revolução Francesa, bem como sua fase republicana, Theremin reconhece nela a virtude de ter conduzido todas as nações européias ao sistema representativo: "Os reis aceitaram o sistema representativo, e os povos aceitaram o sistema da legitimidade", união essa que sustém a "verdadeiras bases da prosperidade das nações e da estabilidade dos soberanos", pp. 6 e 7. A citação de Theremin, na Memória, foi extraída das páginas 173-175 do seu De l'état présent de l'Europe.
} 
Por outro lado, é mais que provável que o autor da Memória seja José Carneiro da Silva - homem natural de Campos dos Goitacases, político conservador do Regresso e proprietário escravista da açucarocracia fluminense. De todo modo, irrefutável é fato de o campo discursivo a que pertence a Memória conjugar-se perfeitamente com aquele do projeto saquarema: conservação dos interesses dos homens de volumoso capital (o que inclui o abastecimento de mão-de-obra barata) para viabilizar a construção de um grandioso império nos trópicos. Na prática, isso se realizaria com a edificação de um império constitucional civilizado e escravista, à revelia da gigantesca pressão exercida pela Grã-Bretanha. Ora, tal ideário está perfeitamente sintetizado na Memória sobre o comércio dos escravos.

Mas, por que a Memória foi dada a imprimir anonimamente? É certo que a crítica pública à lei de 1831 realizada pelos conservadores foi uma arma política mais que eficiente, considerada a ascensão assustadoramente rápida com que o grupo impôs seu domínio sobre os demais. Entretanto, os regressistas vislumbravam em seu horizonte um verdadeiro "muro de bronze" que a Inglaterra jurava erguer para sufocar o tráfico negreiro - atitude reforçada depois da abolição da escravidão no Império britânico em 1838, quando o movimento abolicionista inglês envidou seus maiores esforços para sufocar os sistemas escravistas alhures. Dessa maneira, os conservadores tinham de arranjar sua propaganda com cautela e encontrar o ponto de equilíbrio ideal, onde, de um só golpe, conquistariam a simpatia dos grupos economicamente hegemônicos no Brasil e repeliriam a fúria do Foreign Office ou qualquer guerra extemporânea. Daí seu interesse em, por um lado, esquentar os debates sobre o tráfico de africanos quando na oposição (a partir de 1836) e, por outro, refreá-lo quando no poder (efetivamente, a partir de 1838), uma vez que a estratégia de cooptação política poderia se transformar em profundo infortúnio diplomático. Tal como a Memória saiu anônima da tipografia de Villeneuve em 1838, assim também o projeto de Barbacena de 1837 sobre a revogação da lei de 1831 dormitou tranqüilamente na gaveta saquarema durante o mesmo ano.

Por fim, há ainda o obstáculo institucional. O Estado brasileiro tinha, afinal de contas, abolido o tráfico de africanos, e isso significava que a opinião política de um grupo oposicionista não poderia ser mecanicamente transformada em política de Estado, sob pena de o Governo, desrespeitando as próprias leis, devorar-se a si mesmo. Não é por acaso que, justamente em 1838, Vasconcelos garantiu ao Parlamento total respeito à lei de 1831, depois que Montezuma o interpelou para que emitisse as opiniões de seu Gabinete sobre o trá- 
fico de escravos, por ele tão propaladamente defendido quando na oposição: "Qualquer que seja o juízo que o ministro da justiça [o próprio Vasconcelos] forme a respeito da lei de 7 de Novembro de 1831, há de ter fiel e religiosa execução enquanto for lei de estado; nem é crível que haja um ministro que emita a opinião que não quer que se executem os tratados, que não quer que se executem as leis." ${ }^{49}$ Naquele mesmo ano, era lançado, fora do Parlamento, mas pela tipografia dos conservadores, a Memória sobre o comércio dos escravos. Imprimir um nome na capa, àquela altura em que os conservadores estavam com as rédeas do governo nas mãos, poderia colocar o recém-fundado partido na mira direta do cruzeiro inglês - posição um tanto desconfortável. Eles certamente preferiam um anonimato que os mantivesse nas glórias do poder a um ilustre nome que os arrojasse à infâmia do desgoverno.

\section{Memória sobre o comércio dos escravos, em que se pretende mostrar que este trafico é, para eles, antes um bem do que um mal. Escrita por *** Natural dos Campos dos Goitacazes. Rio de Janeiro: Typographia Imperial e Constitucio- nal de J.Villeneuve, 1838, 13pp.}

Todos sabem que a maior parte das nações africanas vivem em contínuas guerras; que tratam seus prisioneiros com a última barbaridade, e que, finalmente, quando não podem, ou não têm meios de os vender, passam todos ao fio da espada, e, para opróbrio da humanidade, em algumas partes os cortam no açougue como se fossem irracionais, e não se envergonham de terem o infame e repugnante costume de comprarem e comerem a carne de seus semelhantes.

Seria sumamente extenso, se quisesse tratar miudamente do quanto sofrem aqueles desgraçados negros que uma vez foram feitos prisioneiros! Passemos em silêncio esses quadros horrorosos; o pequeno esboço que acima fiz, pode fazer compreender quais serão os tratamentos por que passam estas desgraçadas vítimas em poder de uns senhores que ainda são mais ferozes que os leões e os tigres que os cercam.

\footnotetext{
${ }^{49}$ ACD, 4 de julho de 1838, pp. 33-34.

${ }^{50}$ Para esta edição, atualizou-se a ortografia do documento. As notas com asterisco são do autor da Memória.
} 
De que maiores vantagens não gozam os negros que, sendo feitos prisioneiros, são vendidos às nações cultas e civilizadas! É certo que, entre estas, há alguns senhores que, esquecidos dos princípios da humanidade, os tratam com dureza; mas estes senhores são mais raros do que comumente se pensa, e não devem contrabalançar aqueles que, guiados por princípios pios e humanos, tratam os seus escravos com comiseração, cujo número por felicidade cada vez mais se aumenta, à medida que as luzes se multiplicam.

Nós sabemos que, por uso geral, os fazendeiros, quando compram escravos, o primeiro passo que dão é vesti-los e sustentá-los como eles nunca foram em seu país natal, ainda no estado de liberdade; e passam depois a mandar-lhes ensinar a doutrina cristã, e fazê-los compreender a excelência da religião que professamos, finalmente a fazê-los de pagãos e idólatras católicos romanos. E quantas almas por este meio não se salvam, já recebendo o batismo logo que são comprados, ou depois de estarem instruídos nos principais mistérios da fé: fazendo-os observar a religião que se lhes ensina, administrando-se-lhes os sacramentos e todos os saudáveis meios que ela, sempre humana, sempre sábia e sempre santa, lhes subministra para a sua salvação. É, fundada nestes princípios, que a igreja tolera e aprova o tráfico de escravos, muito persuadida que, ainda que se abolisse entre nós este tráfico, eles por isso não seriam mais felizes, porque as nações africanas nunca deixarão de guerrearem-se e de tratarem os seus prisioneiros como acima fiz ver, sem disto resultar proveito algum.

Pelo contrário, quantos há que vivem felizes em poder de seus senhores brancos? Eu tenho visto escravos que só têm desta condição o nome. Oficiais peritos, eles não só trabalham para seus senhores, como para si, e chegam por meios lícitos a ajuntar o dinheiro necessário para sua liberdade, que algumas vezes chega a alto preço.

Tenho visto escravos senhores de escravos, com plantações, criações de gado vacum e cavalar, e finalmente com um pecúlio vasto e rendoso. Tenho visto muitos escravos libertarem-se, tornarem-se grandes proprietários, serem soldados, chegarem a oficiais de patente, e servirem outros empregos públicos que são tão úteis ao Estado.

Quantos e quantos oficiais de ofícios e mesmo de outras ordens mais superiores que, noutro tempo, foram escravos e hoje vivem com suas famílias, cooperando para o bem do estado nas obras e empregos em que são ocupados, aumentando a população e o esplendor da nação, que os tem naturalizado! 
Sem a escravatura, o que seria n'América o seu comércio de exportação! Com escravos é que se trabalha nas minas, e que se tiram esse precioso metal tão desejado, esses diamantes que têm sido de um tão grande recurso ao estado; essa lucrativa e sobretudo interessante lavoura, principal riqueza do Brasil, e d'América em geral, da qual a Europa mesma não pode mais prescindir.

É de escravos que se compõe a maior parte da tripulação de nossas embarcações de cabotagem, que abastecem as nossas cidades marítimas dos efeitos das outras províncias, por isso que, em um país tão extenso e tão despovoado, é custosíssimo achar homens livres para marinheiros ${ }^{*}$. Estas reflexões me levariam muito longe, e precisavam mesmo de uma pena mais fecunda que a minha; portanto vou transcrever de um autor francês uma passagem que servirá de provar o que acima me refiro.

"É a este povo laborioso (fala dos negros), que nós devemos a cultura e a fertilidade de nossas colônias da América. Não é aqui o lugar para discutir se o tráfico dos negros deve ser proibido. Aqueles que, por uma parte, tem corrido à África e tem sido testemunhas dos excessos bárbaros que acompanham sempre as guerras contínuas que despovoam estas regiões; aqueles que viram os desgraçados prisioneiros reduzidos a pastar a erva dos campos; aqueles que, por outra parte, tem visto os colonos honestos trabalhar por fazer a felicidade dos negros de suas habitações, e que souberam, da boca dos mesmos negros, que, em tal habitação, eles eram mais felizes que em seu país natal; aqueles

\footnotetext{
* Geralmente se diz que a introdução das máquinas no Brasil deve fazer cessar a precisão de maior número de braços. Nos países manufatureiros não duvido que as máquinas diminuam consideravelmente o número de trabalhadores; mas não acontece o mesmo nos países agricultores de açúcar ou de café. Por exemplo, nas fábricas de açúcar, as máquinas que mais lhes convêm são as de vapor ou água, as quais, para fazerem um serviço regular e correspondente a tais fábricas, exigem, pelo menos, duzentos trabalhadores: e qual será o proprietário que, no nosso atual estado de população, possa ajustar duzentos jornaleiros para trabalharem em uma fábrica de açúcar? No caso mesmo que lhe fosse possível achar tal número, não os poderia ajustar por menos de 20\$000rs mensais, o que produz uma soma de 48:000\$000 rs anuais. Suponhamos, por um momento, que os pudesse ajustar por metade: 24:000\$000 rs juntos às mais despesas indispensáveis de uma destas fábricas, não deixarão de arruinar a mais rendosa, e deixá-la desde o primeiro ano sem meios de poder continuar, e cairá infalivelmente. O melhor recurso que presentemente temos para minorar tais inconvenientes, é procurarmos a introdução de colonos, a fim de que tenhamos um rápido aumento na nossa população, porque só assim poderão baixar de preço os jornaleiros, e então serão empregados em nossas fábricas e lavouras, ao menos em alguns serviços.
} 
sobretudo, que observaram quanto são dóceis, civilizados e humanos os negros que se têm tido a paciência de bem instruir na religião, serão forçados a convir que o tráfico de escravos é de fato um bem para eles, tanto como para seus senhores. Os desastres de nossas colônias, os males recentes de São Domingos bastarão, sem dúvida, para apreciar o sistema da sociedade dos pretendidos amigos dos negros, à qual se é devedor de todas essas horrorosas carnificinas, que têm ensangüentado o território francês na América."

Esses pretendidos amigos dos negros, como chama o autor francês, não podem deixar de ser reputados como uns incendiários e hipócritas que, nada menos tendem, com seus capciosos discursos, que o verem renovar-se no seio do seu próprio país e nesta pátria, cujo nome só tem produzido tão heróicas ações, as cenas, que a história nos conserva da antiga Itália, da Sicília, da Sarmácia, do Haiti e outras partes.

$\mathrm{Na}$ verdade custa a sofrer, e nem se pode olhar sem horror para estes filantropos que, manchando o sentido desta palavra, preferem antes prestar esses pretendidos serviços às nações bárbaras africanas, que nem ao menos lhes agradecem, e que até os reputam como uma opressão, do que a seu bem estar e da nação que os alimenta.

Os governos europeus clamam contra essa opressão que sofrem os Africanos; mas são outros os princípios que os guiam, e senão, vejamos o que diz Mr.Carlos Theremin no seu excelente Tratado do estado presente da Europa, cap.14. "Assim como nós especulávamos há pouco tempo em nossas feiras e em nossos portos sobre o comércio dos negros, que era um dos nossos principais interesses comerciais, assim também os Mouros continuam a especular entre si sobre suas enseadas, e em seus Bazars, sobre o comércio dos brancos, que é o seu principal ou único objeto de comércio. Seus reis ou capitães de corsários, traficam com os mercadores de escravos, da liberdade, da vida e dos corpos de nossos pais, de nossas mulheres, de nossos filhos e de nossas filhas. Um desse bárbaros se obriga a fornecer um certo número de homens obreiros ou lavradores, a tanto por cabeça; outro ajusta-se por cem moças núbeis; um terceiro vai roubar ao acaso, e toma tudo que encontra, homens e rebanhos.

"Sobre essas costas meridionais da Espanha, sobre todas as da Itália, da Sicília e Sardenha, os habitantes são surpreendidos de improviso por uma algazarra, muitas vezes em meio de um passeio ou de uma partida de prazer; os que podem fogem, os mais são presos, amarrados e conduzidos para as costas d'África, para serem vendidos. Ali, eles sofrem todos os males, que pode inventar a avareza e a crueldade mais refinada. Não é unicamente os frutos de seus 
trabalhos que se pedem, é a esperança de um rico resgate, que os faz maltratar ainda mais, a fim de que ele venha logo; diariamente os punem, porque não são resgatados, até que morrem sob os golpes ..... E nós que temos abolido o comércio dos negros, deixamos continuar o dos nossos compatriotas, e nenhuma potência se arma pela generosa, mas fácil empresa proposta por Sidney Smith (*). E a Inglaterra, senhora do Mediterrâneo e do Adriático, pela posse de Gibraltar, de Malta e das ilhas Iônicas, favorece antes que ela não tolera este ignominioso tráfico, assim como todas as potências, que concluem tratados com os Barbarescos! E os membros do parlamento britânico, que têm compatriotas, e talvez amigos ou parentes em os banhos de Argel, não se tem ainda explicado, e não tem, achado um novo Wilberforce!

"De certo a humanidade e os princípios da eterna justiça, são alguma coisa depois desse acordo unânime, que tem subtraído à cobiça européia as gerações africanas, e sobretudo depois do religioso tratado concluído entre a Rússia, Áustria e Prússia. Mas como isto se faz? Enquanto subtraímos da escravidão os africanos, nós deixamos reduzidos à escravidão os povos civilizados, nossos compatriotas, por outros africanos! Nós renunciamos a nossa própria cobiça, e deixamos um livre curso à cobiça dos Barbarescos; será porque somos as vítimas!"

Muitos destes governos não querem escravos no Brasil, porque calculam de antemão, e vêm que futuro brilhante espera o Brasil. A feliz situação deste Império que, bem como um disforme gigante, pode estender a sua cabeça para a África, a sua mão direita para Ásia, a esquerda para a Europa, e o resto do corpo por toda a América, não havendo talvez região no mundo mais bem colocada para comerciar com todas as partes do nosso Globo, sua extensão, sua fertilidade, sua imensa exportação que, contudo, não é a vigésima parte da que podem fazer seus excelentes e espaçosos portos, sua preciosa madeira de construção e seus outros numerosos recursos, tudo atemoriza e assusta a esses grandes políticos, e por isso procuram destruir as bases da lavoura, única

\footnotetext{
* Foi necessário que o governo francês recebesse muitas afrontas, e que mesmo a sua política interessasse, para resolver-se a fazer a conquista de Argel, Constantine, etc; conquista que há muito deveria ter sido feita, e com a qual se teriam poupado grandes opróbrios e desgraças.
} 
coisa capaz de fazer o Brasil chegar a uma categoria, que nenhum reino ou império lhe poderá igualar.

Assim conheçam seus filhos, que da paz e união das partes deste grande todo depende toda sua prosperidade, presente e futura, e que por isso lancem para muito longe essas sugestões com que não cessam de os influir, com o fim unicamente de retardar a marcha de sua grandeza, e de desmoronar mesmo, se tanto for possível, este agigantado império que, ainda em embrião, tanto os assusta.

Quando porém o Brasil contar em seu seio uma população correspondente a seu território: quando o seu comércio for tão extenso, quanto é capaz sua fertilidade e seus grandes meios; quando a indústria européia tiver, pela introdução das artes e ofícios e competentes máquinas, feito menos precisos um grande número de braços para suster e fazer andar nossos trabalhos, então, digo eu também, este comércio deve ser abolido, e ainda assim com aquela gradação que deve ter, para se evitar na marcha dos acontecimentos saltos que sempre são nocivos. 